\title{
Performance Evaluation of Equity Funds: 2017-2019
}

\author{
Rivandi Uchok Imanuel Sianipar ${ }^{1}$ S(D) $\varangle$, Bambang Mulyana ${ }^{2}$ (D) and Sri Marti Pramudena ${ }^{3}$ 8 (D) \\ ${ }^{123}$ Universitas Mercu Buana, Indonesia \\ $\triangle$ Corresponding Author: Rivandi Uchok Imanuel Sianipar, E-mail: rivandisianipar@gmail.com
}

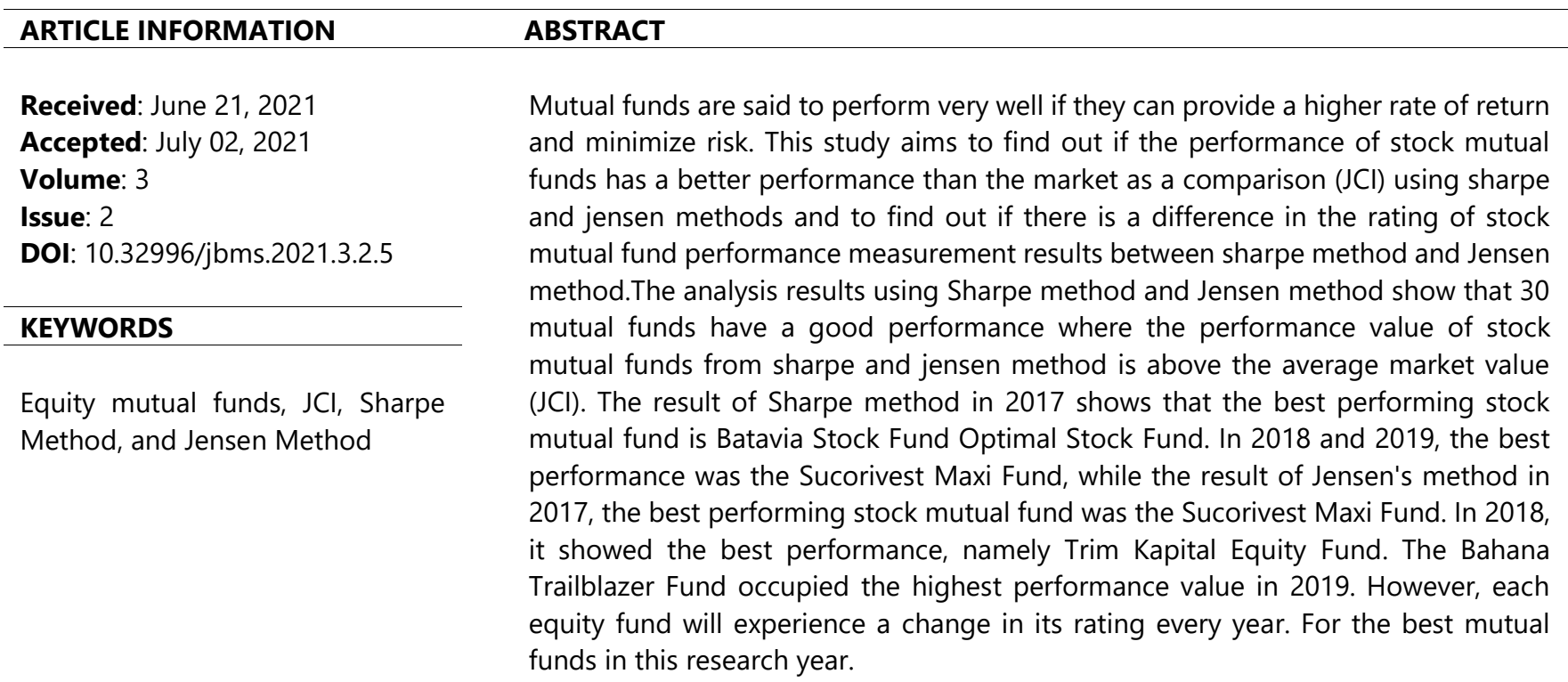

\section{Introduction}

In this modern era, investment becomes an essential need for society, so many kinds of investments are offered to the community. These include property, securities (deposits, stocks, bonds), precious metals, jewellery, or other forms. Investment According to ((Sunariyah, 2010, p. 4)) "investment is an investment for one or more assets owned and usually long-term in the hope of gaining profit in the future". Simply put, an investment can be defined as an attempt to spend some money or funds on something aimed at making a profit in the future.

In recent years precisely in March 2015 the Indonesia Stock Exchange conducted Kampaye National Movement of Love Capital Market with a program carried out "Yuk Nabung Saham" to grow new investors in Indonesia, as well as with the support of millennials who are members of a stock community took part in the success of this campaign to grow new investors to make the Indonesian capital market more passionate. This can be seen how the growth of new investors from 2015 to 2019 as shown below:

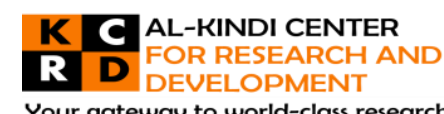
Your gateway to world-class research

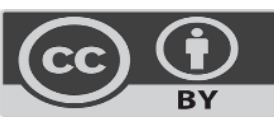

Published by Al-Kindi Center for Research and Development. Copyright (c) the author(s). This open access article is distributed under a Creative Commons Attribution (CC-BY) 4.0 license 


\section{New Investor Growth}

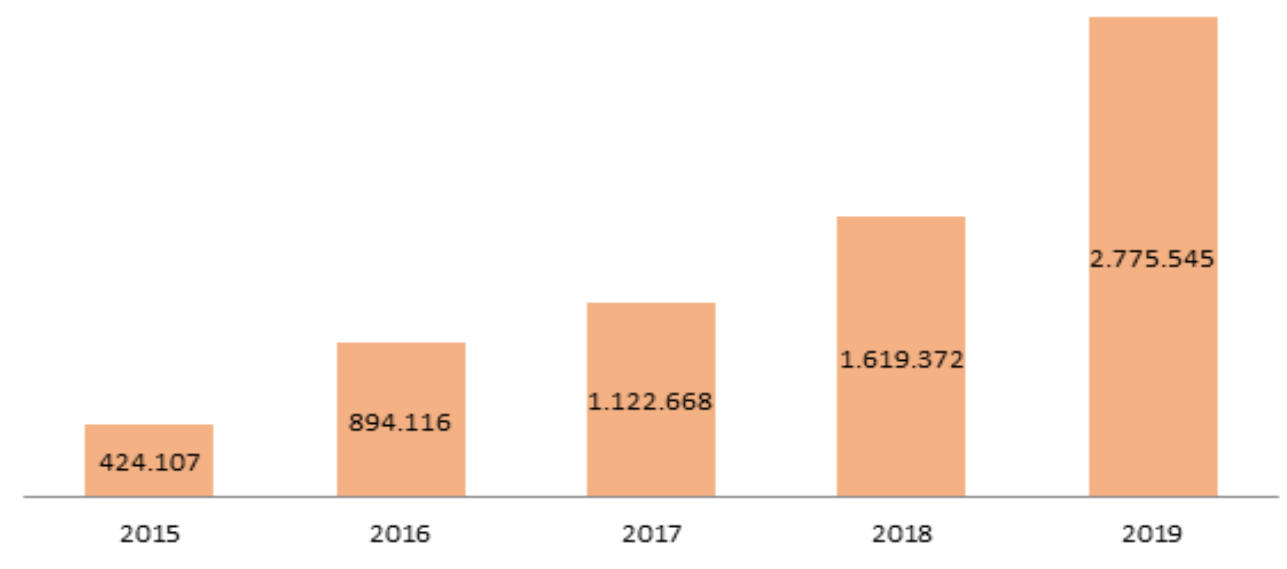

Figure 1.1

New Investor Growth 2015-2019

Source : (KSEI, 2020)

In the picture above, the growth of new investors in the first year in the campaign of the National Movement for Love of Capital Market with the Yuk Nabung Program of Investor Shares has only increased by $52.56 \%$, as well as in the second year experienced growth of $20.36 \%$, up to the fourth year of $41.65 \%$. The increase of new investors is not driven entirely by the growth of investors in stock instruments but rather driven by new investors in mutual fund investments. This can be seen in the growth of new investors of mutual funds, because these new investors have not understood much investing in the world of capital markets, especially stocks, where in Pramudena (2020), there are two approaches to analyzing stocks namely technical and fundamental analysis. Technical analysis is an effort to observe stocks according to their movements over time while fundamentals observe the stock price by observing and studying the company's finances as a step in the valuation of the company's shares. In this case, it takes time to learn it so that new investors choose to invest in mutual funds first, to maintain the security of their investment capital before investing in stocks. New investors want to concentrate their portfolios with the same level of risk as the return on yield, as is the case with Markowitz's efficient portfolio theory. This theory combines mutual return and risk measurements, where risk factors can be minimized by diversifying various investment instruments (Untu, 2017, p. 9), assets or securities into portfolio form. We can see the growth in the chart below:

\section{Growth of New Investors in Mutual Fund Instruments}

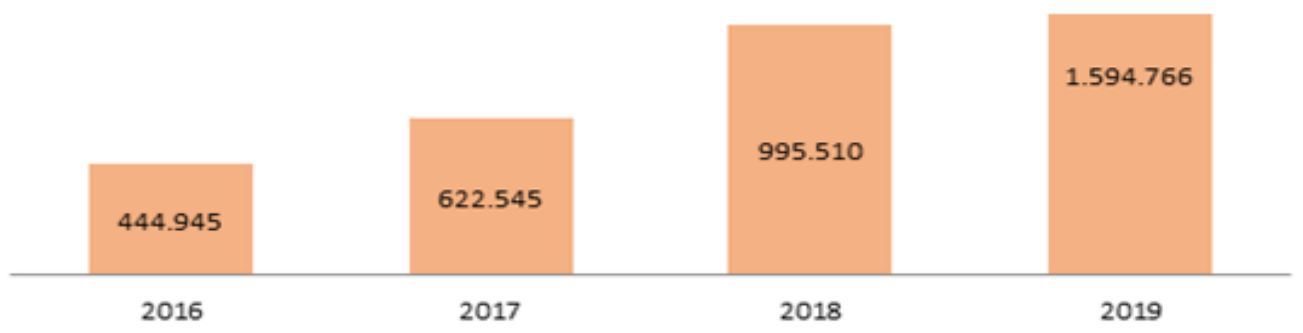

Figure 1.2

Growth of New Investors in Mutual Fund Instruments 2016-2019

Source : (KSEl, 2020) 
The bar chart above shows that mutual funds account for more than $50 \%$ of new investors in the capital market. Mutual funds are derived from the word "mutual" which means keep or maintain and the word "fund" means money, so mutual funds are a set of money that is maintained, which means mutual funds are investments that raise funds from various investors managed by investment managers. According to Capital Market Law No. 8 of 1995, Article 1 paragraph 27 of mutual funds is defined as a forum used to raise funds from the investor community to be further invested in the Securities Portfolio by the Investment Manager.

In its development mutual funds in Indonesia experienced a fairly siknifikan growth, as shown in the picture below:

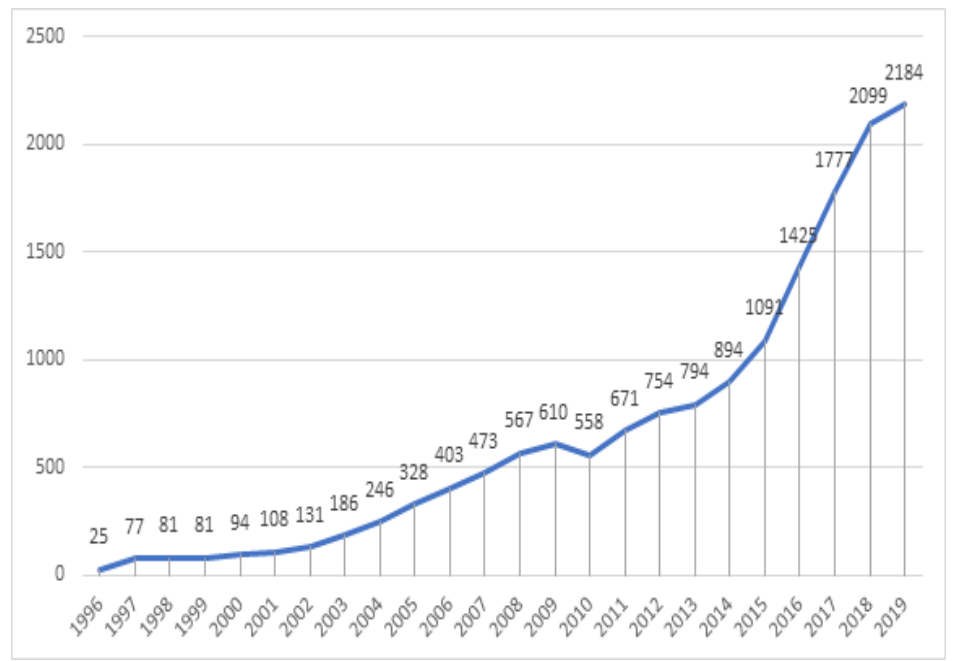

Figure 1.3

Growth in The Number of Mutual Fund Products

Source : (Otoritas Jasa Keuangan (OJK), 2021)

In addition to the growth of the number of mutual fund products offered to investors and the growth of new investors that always increase every year in Indonesia, according to Yiqing Zu (2016), mutual funds also play a large role in the secondary market as traders and investors. But also followed by the growth of the Country's GDP, which continues to experience positive growth every year, Beck et al. (2000) found that financial developments had a large and positive impact on total productivity growth factors, which in turn led to GDP growth, can be seen below:

\section{Indonesia GDP Growth per Capita}

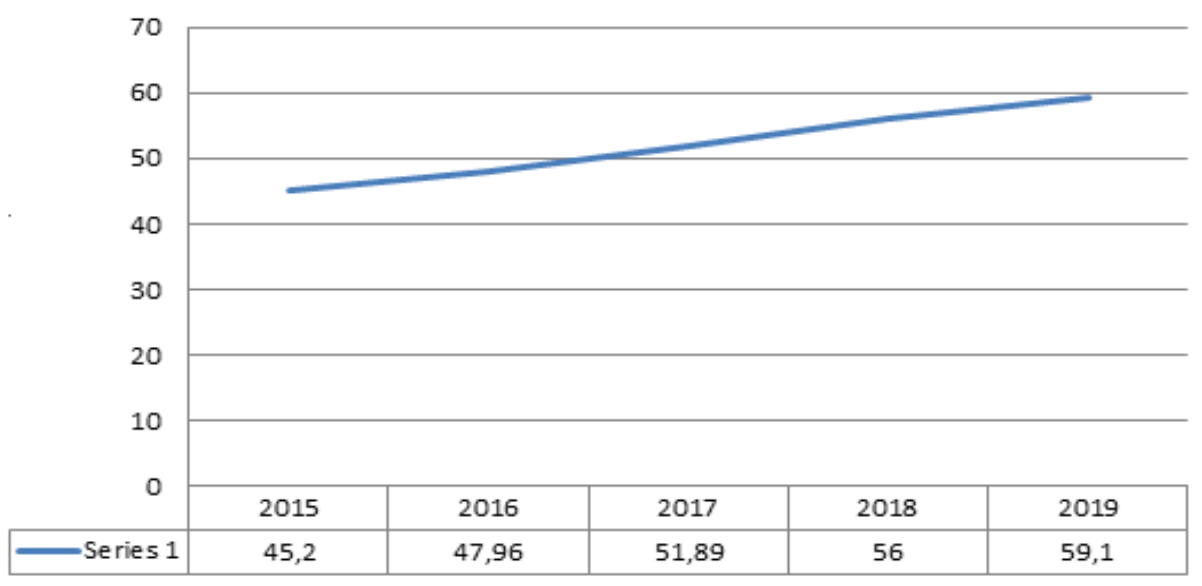

Figure 1.4

Indonesia GDP Growth per Capita 2015-2019

Source : (Badan Pusat Statistik, 2020)

Where the average GDP growth of Indonesia for 5 years grew 3.4, theoretically, GDP growth is related to the portfolio's performance in investors' investments so that they can know the portfolio's performance. 
In general, mutual funds are divided into four namely money market, fixed income, mixed and stock mutual funds. A money market fund is a type of mutual fund that invests in a type of money market investment instrument with a maturity period of less than one year. Fixed-income mutual funds are a type of mutual fund that invests at least 80 percent of its assets in the form of debt or bond securities. A mixed fund is a type of mutual fund allocating its investment funds in a varied portfolio. Its investment instruments can be in the form of stocks and combined with bonds. An equity fund is a type of mutual fund that invests at least 80 percent of its assets in the form of equity securities.

In Barus (2013) mutual funds, risk information becomes important in comparing the investment performance of mutual funds. Performance measurement taking into account risk factors provides investors with information about the extent to which an investment manager's results or performance are associated with the risks taken to achieve that performance. The measurement of mutual fund performance is also seen from the amount of NAB / unit and the return generated. In the four types of mutual funds we can see on the chart below the growth of the Net Asset Value of each mutual fund over the past five years:

Net Asset Value

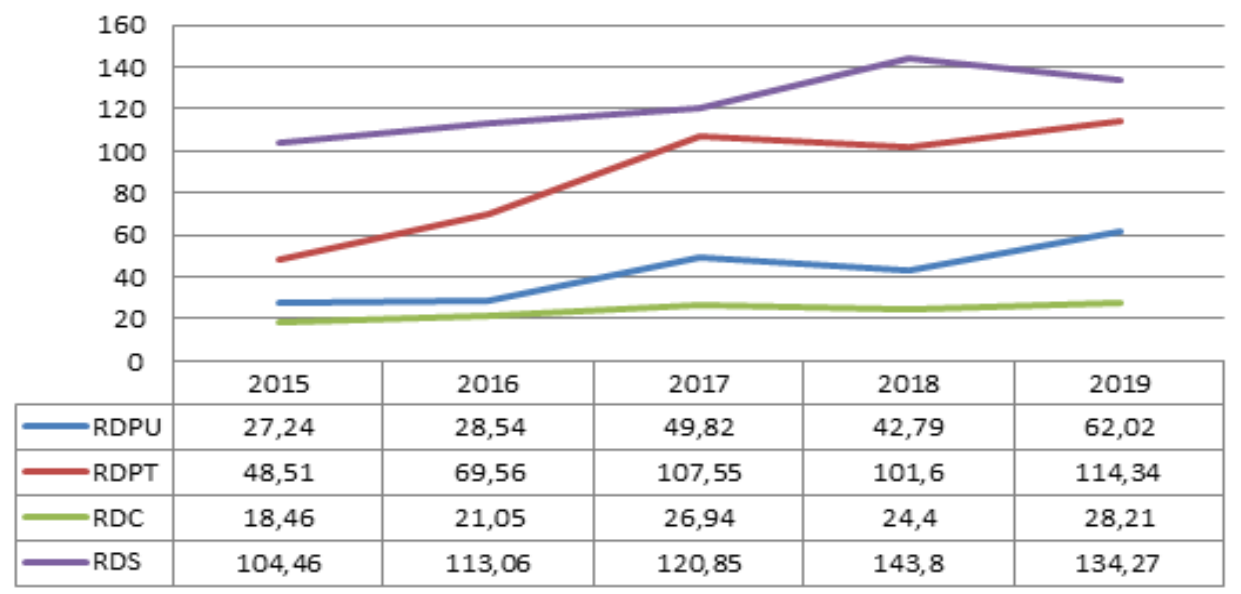

Figure 1.5

Net Asset Value 2015-2019

Source: (Otoritas Jasa Keuangan (OJK), 2021)

The above phenomenon shows the Net Asset Value of Equity Mutual Funds, an investment instrument of mutual funds that have the highest risk among other types of mutual funds, becoming the mutual fund of choice for Investors to invest their capital. So in this research focuses on Equity Mutual Funds because it is seen that the interest of the largest mutual fund investors is in Equity Mutual Funds.

In this study, the method used to measure the performance of equity mutual funds is sharpe method and Jansen method that can describe the investment manager's ability to manage stock mutual funds that measure how much yield is added.

Although there is no certainty that the performance of mutual funds that perform well in the past can perform the same in the future, mutual funds that perform well in the past have the opportunity to have a good performance also in the future. Each type of Mutual Fund has a different performance, depending on how the investment manager company manages. A mutual fund is said to perform very well if it can provide a higher rate of return and minimize risk.

New investors who want to invest their funds in Mutual Funds need to know which mutual funds from which investment management companies perform best. Mutual funds are said to perform well when providing a high rate of return with reasonable and good risk. The exposure of the performance of equity funds in Indonesia is expected to provide an objective picture of the performance condition of equity funds in Indonesia. Therefore, it will conduct a study entitled: Performance Evaluation of Equity Funds. To find out which stock mutual funds performed best in that period.

\section{Literature Review}

\subsection{Investment}


The term investment can be related to a wide variety of activities. Investment activities that are generally carried out are investing a certain amount of funds in rill assets (Land, Gold, Machinery, Buildings) and financial assets / paper assets (Deposits, Shares, Mutual Funds, Bonds), According to Sunariyah (2010, p. 4) "investment is investment for one or more assets owned and usually long-term in the hope of gaining profit in the future" while according to Gitman and Joehnk (2017) is investment is any vehicle into which funds can be played with expectations that it will generate positive income and / or preserve or increase its value. Investment sense, according to Investopedia, investment is the act of allocating resources, usually money, in the hope of generating income or profit. You can invest in a variety of businesses, such as using money to start a business, or in assets, such as buying real estate in hopes of being resold later at a higher price.

\subsection{Mutual funds}

According to Northcott (2014, p. 11) mutual funds are a means to invest in something along with other people. The advantage this offers over-investing your money individually has a professional fund manager whose job is to look after the invested funds and make any necessary adjustments according to his or her knowledge and experience. The mutual fund, as a whole, amounts to more money than you could invest alone, which may open up possibilities for investment by a manager who can produce a greater return. According to Capital Market Law No.8 of 1995, article 1, paragraph 27 "Mutual funds are containers used to raise funds from the investor community to be further invested in securities portfolios by investment managers." Mutual funds are also one of the investment instruments in the capital market whose influence in society is increasingly spreading and increasingly in demand.

\subsection{Determinant of Investors choosing Mutual Funds}

Psychological factors are the most dominant factors influencing investment decision making. Macroeconomic and social factors also influence the selection of investment decisions. Market conditions can be fundamental factors of the company and external factors such as socio-political, economic, psychological, regulatory, technological, environmental and legal. All of these factors have an influence on stock investments. According to Chandra (2011), psychological factors such as conservatism and prudence impact investor decision-making. So that from the above, causative factors in investing in mutual funds are divided into several types of mutual funds divided by different levels of risk, such as Money Market Mutual Funds, Fixed Income Mutual Funds, Mixed Mutual and Equity Funds.

\subsection{Types of Mutual Funds}

\subsubsection{Money Market Mutual Funds}

Money Market Mutual Fund (RDPU) is a mutual fund that has the lowest risk compared to other mutual funds. Choice of investment instruments in the money market such as time deposits, deposit / Bank Indonesia certificates, and short-term bonds. Types of mutual funds suitable for short-term investment purposes, prioritising capital security rather than growth (Safety Fund).

\subsubsection{Fixed Income Mutual Fund}

Fixed Income Mutual Fund (RDPT) is a mutual fund whose growth is relatively more stable and volatile than stock mutual funds. The composition of investments is focused on investment means that offer definite returns such as: bonds and money markets. Types of mutual funds suitable for investors seeking optimal interest rate benefits by prioritizing stable and consistent income (Income Fund).

\subsubsection{Mixed Mutual Funds}

A Mixed Fund (RDC) is a slightly volatile fund with relatively stable growth than equity funds. This fund prioritizes investments in stocks and bonds with certain positions to support the achievement of investment objectives. This fund is for investors who want adequate income by taking advantage of investment growth opportunities in the long run.

\subsubsection{Equity Funds}

Equity Mutual Funds (RDS) are mutual funds whose investment returns from year to year vary widely and tend to fluctuate in line with the development of the market and economic conditions that occur. This mutual fund is suitable for investors who pursue optimal investment value growth in the long-term period (growth fund). Investments that offer the most growth potential are stocks.

\subsection{Benefits of Mutual Funds}

There are several benefits that investors can achieve by investing their funds in mutual funds, among others:

\subsubsection{Managed by professional investment management}


Invesment Maneger is a professional who is appointed to manage the invested funds. Invesment Manager has an important role for investors who do not have enough time to manage the capital they invest directly. Also, for investors who cannot research the company and its investments directly.

\subsubsection{Lower the risk}

Diversification is expected to reduce the risks that will arise. Keep in mind. Mutual funds are investment products that are not only focused on one type of company. Of course, this will reduce the risk, although this does not close the possibility to cover the risks that come.

\subsubsection{1. two types of risks need to be known, namely, gain risk and loss risk.}

Gain risk is the circumstance in which you profit from the invested capital.

\subsubsection{Risk of loss is a condition in which it can suffer losses.}

\subsubsection{Transparent Information}

This investment provides information related to the portfolio on an ongoing basis. This is done so that investors can monitor the profits, costs, and risks faced. As the person managing the fund, the Investment Manager is also obliged to issue semiannual or annual financial statements and announce the value of net assets received.

\subsubsection{Safe}

The level of risk obtained depends on what type of mutual fund you choose. At least you don't have to worry anymore because the invested funds are managed by a professional Investment Manager (MI).

\subsubsection{High liquidity}

Liquidity is a company's ability to pay its short-term obligations. If the company has higher liquidity, it can be trusted to pay its short-term obligations very well.

\subsection{Basic Investment Decisions}

The basis of investment decisions consists of the expected return level, the level of risk, and the relationship between return and risk (Tandelilin, 2010, pp. 9-11).

\subsubsection{Return}

The main reason people invest is to make a profit. In the context of investment management, the level of investment return is referred to as return. The return that investors expect from their investments is compensation for opportunity costs and the risk of decreased purchasing power due to the influence of inflation. In the context of investment management, it is necessary to distinguish between the expected return and the return that occurs. The expected return is the level of return anticipated by investors in the future, while the return that occurs or return table is the level of return that investors have obtained in the past.

\subsubsection{Risk}

Risk is defined as the possibility of an actual return that is different from the expected return. In economics in general and investment science in particular, there is an assumption that investors are rational beings. Rational investors certainly won't like uncertainty or risk. The investor's attitude towards risk will depend heavily on the investor's preference for risk.

\subsubsection{Risk and return relationship}

The relationship between risk and return expectations is direct and linear. This means that the greater the risk of an investment, the greater the return on expectations for the asset, and vice versa.

\subsection{Mutual Fund Performance}

The performance of a mutual fund is the ability to analyze a mutual fund by evaluating the development of the fund by the investment manager in creating or giving profit to investors. In the performance of variable mutual funds - variables used are:

\subsubsection{Net Asset Value}

Net Asset Value (NAV) per participation unit is the fair price of a Mutual Fund's portfolio after deducting operational costs and then divided by the number of shares/units that have been outstanding (owned by investors) at that time.

\subsubsection{Mutual Fund Return}

Return of stock mutual funds is the amount of yield obtained by investors from a number of funds invested in a stock mutual fund in a certain period. The return value of this mutual fund is obtained from NAB per participation unit for each equity mutual fund.

\subsubsection{Market Return}

The market return is the level of profit gained from market performance. The benchmark variable used in this study is the Composite Stock Price Index. The Composite Stock Price Index is one of the stock market indices used by the Indonesia Stock Exchange. 


\subsubsection{Risk-Free Return}

Risk-free profit is the profit gained from investment instruments that have very little risk. Risk-free investments are measured using the $\mathrm{BI}$ rate.

BI Rate is a policy rate that reflects the monetary policy stance set by bank Indonesia and announced to the public.

To see how the performance of a mutual fund, can be done analysis with several methods, including.

\subsubsection{Sharpe Method}

Tandelilin (2001) explains the Sharpe Method developed by William Sharpe. Sharpe method bases its calculation on the concept of the capital market line as a guess. The capital market line describes the relationship between return expectations and the real risk of an efficient portfolio on a balanced market.

\subsubsection{Jansen Method}

Tandelilin (2001) explains jensen's alpha method is one of the Risk-Adjusted Performance models introduced by Michael C. Jensen. Jensen Method shows the difference between the actual return rate obtained by the portfolio and the expected return rate if the portfolio is on the capital market line.

\subsection{Previous Research}

The hypothesis is a temporary answer to a problem that is still presumption or guesswork because the truth still has to be proven through research or research. Technically, hypotheses are state statements about the state of the population to be tested for correctness based on data obtained from research samples (Suryabrata., 2008).

Based on the conceptual research framework and the results of the previous research above, the hypotheses in the study are as follows:

H1 = Stock Mutual Fund has a better performance than its market performance by using Sharpe Method in 2017-2019.

H2 = Stock Mutual Fund has a better performance than its market performance by using Jensen Method in 2017-2019.

$\mathrm{H} 3$ = The best performing stock mutual fund by looking at the rating of each mutual fund by referring to sharpe method and Jansen method in 2017-2019.

\section{Research Methods}

According to Creswell (2020), the sample is a subgroup of the target population that the researcher plans to study for generalizing the target population. If the population is large and researchers are unlikely to study everything in the population due to limited funds, energy, and time, researchers can use samples taken from that population. Therefore, samples taken from the population must be strictly representative. The technique in sampling is saturated sampling. According to Sugiyono (2018, p. 85) saturated sampling is a sampling technique when all members of the population are used as samples. Another term of saturated sampling is a census, where sampling is all stock mutual funds with the most managed funds as many as 30 mutual funds.

\section{Results}

\subsection{Sharpe Method}

\begin{tabular}{|c|c|c|c|c|c|c|c|}
\hline \multirow[t]{2}{*}{ No } & \multirow[t]{2}{*}{ Mutual Fund } & \multicolumn{2}{|l|}{2017} & \multicolumn{2}{|l|}{2018} & \multicolumn{2}{|l|}{2019} \\
\hline & & $\begin{array}{l}\text { Sharpe } \\
\text { (\%) }\end{array}$ & Level & $\begin{array}{l}\text { Sharpe } \\
\text { (\%) }\end{array}$ & Level & $\begin{array}{l}\text { Sharpe } \\
\text { (\%) }\end{array}$ & Level \\
\hline 1 & $\begin{array}{l}\text { Batavia Dana } \\
\text { Saham }\end{array}$ & 42,02 & 8 & 0,44 & 29 & 27,55 & 23 \\
\hline 2 & $\begin{array}{l}\text { Batavia Dana } \\
\text { Saham Optimal }\end{array}$ & 47,56 & 1 & 21,95 & 14 & 34,82 & 5 \\
\hline 3 & $\begin{array}{l}\text { Mandiri Cerdas } \\
\text { Bangsa }\end{array}$ & 41,52 & 12 & 20,44 & 22 & 30,47 & 15 \\
\hline 4 & $\begin{array}{l}\text { Bahana Dana } \\
\text { Prima }\end{array}$ & 41,25 & 14 & 20,60 & 21 & 23,07 & 26 \\
\hline 5 & $\begin{array}{l}\text { Bahana } \\
\text { Trailblazer } \\
\text { Fund }\end{array}$ & 41,65 & 9 & 21,59 & 15 & 2,13 & 30 \\
\hline
\end{tabular}




\begin{tabular}{|c|c|c|c|c|c|c|c|}
\hline 6 & $\begin{array}{l}\text { Schroder } 90 \\
\text { Plus Equity } \\
\text { Fund }\end{array}$ & 40,30 & 20 & 23,13 & 7 & 32,98 & 10 \\
\hline 7 & $\begin{array}{l}\text { Schroder Dana } \\
\text { Istimewa }\end{array}$ & 40,94 & 18 & 24,20 & 4 & 34,02 & 7 \\
\hline 8 & $\begin{array}{l}\text { Schroder Dana } \\
\text { Prestasi }\end{array}$ & 40,97 & 16 & 24,00 & 5 & 33,67 & 9 \\
\hline 9 & $\begin{array}{l}\text { Schroder Dana } \\
\text { Prestasi Plus }\end{array}$ & 43,91 & 4 & 23,58 & 6 & 35,22 & 2 \\
\hline 10 & $\begin{array}{l}\text { Manulife Dana } \\
\text { Saham Kelas A }\end{array}$ & 41,12 & 15 & 20,91 & 19 & 27,91 & 22 \\
\hline 11 & $\begin{array}{l}\text { Manulife } \\
\text { Saham Andalan }\end{array}$ & 41,56 & 11 & 22,70 & 10 & 28,10 & 21 \\
\hline 12 & $\begin{array}{l}\text { Manulife } \\
\text { Saham SMC } \\
\text { Plus }\end{array}$ & 22,17 & 29 & 6,76 & 26 & 23,56 & 25 \\
\hline 13 & $\begin{array}{l}\text { Danareksa } \\
\text { Mawar } \\
\text { Konsumer } 10\end{array}$ & 40,30 & 20 & 21,99 & 13 & 29,69 & 17 \\
\hline 14 & $\begin{array}{l}\text { BNI-AM } \\
\text { Inspiring Equity } \\
\text { Fund }\end{array}$ & 41,45 & 13 & 21,48 & 17 & 28,51 & 19 \\
\hline 15 & $\begin{array}{l}\text { Syailendra } \\
\text { Equity } \\
\text { Opportunity } \\
\text { Fund }\end{array}$ & 40,61 & 19 & 8,65 & 25 & 31,52 & 13 \\
\hline 16 & $\begin{array}{l}\text { Eastspring } \\
\text { Investments } \\
\text { Alpha } \\
\text { Navigator }\end{array}$ & 39,11 & 23 & 2,91 & 28 & 30,46 & 16 \\
\hline 17 & $\begin{array}{l}\text { Eastspring } \\
\text { Investments } \\
\text { Value } \\
\text { Discovery Kelas } \\
\text { A }\end{array}$ & 25,18 & 28 & 21,58 & 16 & 29,17 & 18 \\
\hline 18 & $\begin{array}{l}\text { BNP Paribas } \\
\text { Ekuitas }\end{array}$ & 36,72 & 25 & 21,41 & 18 & 13,68 & 27 \\
\hline 19 & $\begin{array}{l}\text { BNP Paribas } \\
\text { Infrastruktur } \\
\text { Plus }\end{array}$ & 43,34 & 6 & 9,08 & 24 & 28,38 & 20 \\
\hline 20 & $\begin{array}{l}\text { BNP Paribas } \\
\text { Pesona }\end{array}$ & 43,27 & 7 & 22,57 & 11 & 30,99 & 14 \\
\hline 21 & $\begin{array}{l}\text { BNP Paribas } \\
\text { Solaris }\end{array}$ & 46,81 & 2 & 24,66 & 3 & 8,08 & 28 \\
\hline 22 & $\begin{array}{l}\text { Simas } \\
\text { Danamas } \\
\text { Saham } \\
\end{array}$ & 45,07 & 3 & 23,03 & 8 & 31,66 & 12 \\
\hline 23 & $\begin{array}{l}\text { Simas Saham } \\
\text { Bertumbuh }\end{array}$ & 39,97 & 22 & 19,24 & 23 & 26,48 & 24 \\
\hline 24 & $\begin{array}{l}\text { Simas Saham } \\
\text { Unggulan }\end{array}$ & 34,46 & 27 & 20,72 & 20 & 34,91 & 4 \\
\hline 25 & $\begin{array}{l}\text { Tram } \\
\text { Consumption } \\
\text { Plus }\end{array}$ & 36,48 & 26 & 22,22 & 12 & 32,49 & 11 \\
\hline
\end{tabular}




\begin{tabular}{|l|l|l|l|l|l|l|l|}
\hline 26 & $\begin{array}{l}\text { Tram } \\
\text { Infrastructure } \\
\text { Plus }\end{array}$ & 38,90 & 24 & 4,50 & 27 & 35,17 & 3 \\
\hline 27 & Trim Kapital & 41,63 & 10 & 0,32 & 30 & 34,58 & 6 \\
\hline 28 & $\begin{array}{l}\text { Trim Kapital } \\
\text { Plus }\end{array}$ & 40,96 & 17 & 22,95 & 9 & 8,01 & 29 \\
\hline 29 & $\begin{array}{l}\text { Sucorinvest } \\
\text { Equity Fund }\end{array}$ & 43,73 & 5 & 25,76 & 2 & 33,90 & 8 \\
\hline 30 & $\begin{array}{l}\text { Sucorinvest } \\
\text { Maxi Fund }\end{array}$ & 3,66 & 30 & 35,65 & 1 & 42,44 & 1 \\
\hline
\end{tabular}

Based on the above output, the Sharpe Method calculation produces a positive value and exceeds the average market value (JCl) of 0.08 , which is in accordance with Sharpe's theory that a good mutual fund's performance is to generate a positive portfolio value and exceed the market value.

In 2017, it was seen from the rating of Batavia Dana Saham Optimal Equity Fund which is the best among other equity funds, with a value support of $47.56 \%$, followed by BNP Paribas Solaris second place at $46.81 \%$, while the Stock Mutual Fund which has the lowest positive value but exceeds the average market value $(\mathrm{JCl})$ is such invest Maxi Fund 3.66\%.

In 2018, the rating of Sucorivest Maxi Fund was the best among other equity funds, with a value support of $35.65 \%$, followed by the second position of Sucorivest Equity Fund with a value of $25.76 \%$, while the Stock Mutual Fund that had the lowest positive value but exceeded the average market value $(\mathrm{JCl})$ was Trim Kapital Equity Fund with a value of $0.32 \%$.

In 2019, the rating of Sucorivest Maxi Fund was the best among other equity funds, with a value support of $42.44 \%$. The second position was Schroder Dana Prestasi Plus Equity Fund with a value of 35.22\%, while stock mutual funds have the lowest positive value but exceed the market average value $(\mathrm{JCl})$, namely Bahana Trailblazer Fund Share Mutual Fund with a value of $2.13 \%$.

\subsection{Jensen Method}

\begin{tabular}{|c|c|c|c|c|c|c|c|}
\hline \multirow{2}{*}{ No } & \multirow{2}{*}{ Mutual Fund } & \multicolumn{2}{|l|}{2017} & \multicolumn{2}{|l|}{2018} & \multicolumn{2}{|l|}{2019} \\
\hline & & Jensen (\%) & Level & Jensen (\%) & Level & Jensen (\%) & Level \\
\hline 1 & $\begin{array}{l}\text { Batavia Dana } \\
\text { Saham }\end{array}$ & 1,43 & 11 & 532,34 & 2 & 3,07 & 8 \\
\hline 2 & $\begin{array}{l}\text { Batavia Dana } \\
\text { Saham Optimal }\end{array}$ & 0,99 & 28 & 2,12 & 18 & 1,20 & 26 \\
\hline 3 & $\begin{array}{l}\text { Mandiri Cerdas } \\
\text { Bangsa }\end{array}$ & 1,33 & 18 & 2,89 & 9 & 2,05 & 16 \\
\hline 4 & $\begin{array}{l}\text { Bahana Dana } \\
\text { Prima }\end{array}$ & 1,37 & 14 & 2,88 & 10 & 4,27 & 5 \\
\hline 5 & $\begin{array}{l}\text { Bahana } \\
\text { Trailblazer } \\
\text { Fund }\end{array}$ & 1,36 & 15 & 2,45 & 13 & 94,89 & 1 \\
\hline 6 & $\begin{array}{l}\text { Schroder } 90 \\
\text { Plus Equity } \\
\text { Fund }\end{array}$ & 0,96 & 30 & 1,37 & 26 & 1,27 & 25 \\
\hline 7 & $\begin{array}{l}\text { Schroder Dana } \\
\text { Istimewa }\end{array}$ & 1,31 & 21 & 1,34 & 27 & 1,33 & 22 \\
\hline 8 & $\begin{array}{l}\text { Schroder Dana } \\
\text { Prestasi }\end{array}$ & 1,33 & 18 & 1,42 & 25 & 1,40 & 21 \\
\hline 9 & $\begin{array}{l}\text { Schroder Dana } \\
\text { Prestasi Plus }\end{array}$ & 1,16 & 24 & 1,56 & 23 & 1,15 & 29 \\
\hline 10 & $\begin{array}{l}\text { Manulife Dana } \\
\text { Saham Kelas A }\end{array}$ & 1,38 & 13 & 2,73 & 11 & 2,70 & 9 \\
\hline 11 & $\begin{array}{l}\text { Manulife } \\
\text { Saham Andalan }\end{array}$ & 1,31 & 21 & 1,90 & 21 & 2,56 & 10 \\
\hline
\end{tabular}




\begin{tabular}{|c|c|c|c|c|c|c|c|}
\hline 12 & $\begin{array}{l}\text { Manulife } \\
\text { Saham SMC } \\
\text { Plus }\end{array}$ & 3,34 & 2 & 21,76 & 5 & 3,84 & 6 \\
\hline 13 & $\begin{array}{l}\text { Danareksa } \\
\text { Mawar } \\
\text { Konsumer } 10\end{array}$ & 1,40 & 12 & 2,20 & 17 & 2,21 & 15 \\
\hline 14 & $\begin{array}{l}\text { BNI-AM } \\
\text { Inspiring Equity } \\
\text { Fund }\end{array}$ & 1,34 & 17 & 2,44 & 15 & 2,51 & 11 \\
\hline 15 & $\begin{array}{l}\text { Syailendra } \\
\text { Equity } \\
\text { Opportunity } \\
\text { Fund }\end{array}$ & 1,33 & 18 & 15,17 & 6 & 1,76 & 18 \\
\hline 16 & $\begin{array}{l}\text { Eastspring } \\
\text { Investments } \\
\text { Alpha } \\
\text { Navigator }\end{array}$ & 1,70 & 4 & 74,35 & 3 & 2,26 & 14 \\
\hline 17 & $\begin{array}{l}\text { Eastspring } \\
\text { Investments } \\
\text { Value } \\
\text { Discovery Kelas } \\
\text { A }\end{array}$ & 3,02 & 3 & 2,39 & 16 & 2,34 & 12 \\
\hline 18 & $\begin{array}{l}\text { BNP Paribas } \\
\text { Ekuitas }\end{array}$ & 1,67 & 6 & 2,45 & 13 & 10,17 & 4 \\
\hline 19 & $\begin{array}{l}\text { BNP Paribas } \\
\text { Infrastruktur } \\
\text { Plus }\end{array}$ & 1,16 & 24 & 13,39 & 7 & 2,34 & 12 \\
\hline 20 & $\begin{array}{l}\text { BNP Paribas } \\
\text { Pesona }\end{array}$ & 1,22 & 23 & 1,96 & 20 & 1,92 & 17 \\
\hline 21 & $\begin{array}{l}\text { BNP Paribas } \\
\text { Solaris }\end{array}$ & 1,03 & 27 & 1,21 & 28 & 19,50 & 3 \\
\hline 22 & $\begin{array}{l}\text { Simas } \\
\text { Danamas } \\
\text { Saham }\end{array}$ & 0,98 & 29 & 1,45 & 24 & 1,45 & 20 \\
\hline 23 & $\begin{array}{l}\text { Simas Saham } \\
\text { Bertumbuh }\end{array}$ & 1,46 & 10 & 3,59 & 8 & 3,11 & 7 \\
\hline 24 & $\begin{array}{l}\text { Simas Saham } \\
\text { Unggulan }\end{array}$ & 1,70 & 5 & 2,62 & 12 & 1,19 & 27 \\
\hline 25 & $\begin{array}{l}\text { Tram } \\
\text { Consumption } \\
\text { Plus }\end{array}$ & 1,66 & 7 & 2,09 & 19 & 1,62 & 19 \\
\hline 26 & $\begin{array}{l}\text { Tram } \\
\text { Infrastructure } \\
\text { Plus }\end{array}$ & 1,49 & 9 & 37,31 & 4 & 1,16 & 28 \\
\hline 27 & Trim Kapital & 1,52 & 8 & 789,39 & 1 & 1,33 & 22 \\
\hline 28 & $\begin{array}{l}\text { Trim Kapital } \\
\text { Plus }\end{array}$ & 1,36 & 15 & 1,82 & 22 & 20,30 & 2 \\
\hline 29 & $\begin{array}{l}\text { Sucorinvest } \\
\text { Equity Fund }\end{array}$ & 1,14 & 26 & 0,89 & 29 & 1,33 & 22 \\
\hline 30 & $\begin{array}{l}\text { Sucorinvest } \\
\text { Maxi Fund }\end{array}$ & 6,63 & 1 & 0,33 & 30 & 0,53 & 30 \\
\hline
\end{tabular}

Based on the above output, by calculating the Jensen Method produces a positive alpae value and exceeds the market average value $(\mathrm{JCl})$ of 0.08 , which is in accordance with jensen's theory that a good mutual fund's performance is to produce a positive alpha value and exceed the market value. 
In 2017, judging by the rating of Sucorivest Maxi Fund, which performed better among other equity funds, with alpa support value of $6.63 \%$, followed by second-place Manulife Saham SMC Plus with Alpha value of 3.34\%, while Equity Fund which has the lowest positive value but exceeds the market average value $(\mathrm{JCl})$ is Schroder 90 Plus Equity Fund Equity Fund with Alpha $0.96 \%$.

In 2018, trim kapital stock mutual funds performed better among other equity funds, with Alpha support value of $789.39 \%$, followed by Batavia Dana Saham with Alpha value of $532.34 \%$ while Equity Mutual Fund which had the lowest positive value but exceeded the market average value $(\mathrm{JCl})$ namely Sucorivest Maxi Fund Equity Fund with Alpha value of $0.33 \%$.

In 2019, Bahana Trailblazer Fund performed better among other equity funds, with Alpha support value of 94.89\%. The second position was Schroder Dana Prestasi Plus Equity Fund with an Alpha value of $35.22 \%$, while Equity Mutual Fund has the lowest positive value but exceeds the market average value $(\mathrm{JCl})$, namely Sucorivest Maxi Fund Share Mutual Fund with Alpha value of $0.53 \%$.

\subsection{Hypothetical Results}

4.3.1. $\mathrm{H} 1=$ Stock Mutual Fund has performed better than its market performance by using Sharpe Method in 2017-2019.

The results of this study found that the performance of stock mutual funds by calculation using sharpe method showed positive results and exceeded the market value $(\mathrm{JCl})$. This research is in line with research from Pujiarti and Farida (2016), and this hypothesis is acceptable.

4.3.2. $\mathrm{H} 2$ = Stock Mutual Fund has a better performance than its market performance by using Jensen Method in 2017-2019.

The results of this study found that the performance of stock mutual funds with calculations using the jensen method showed positive alpha results and exceeded the market value (JCl). This research is in line with research from Pujiarti and Faridah (2016), and this hypothesis is acceptable.

4.3.3. $\mathrm{H} 3$ = The best performing stock mutual fund by looking at the rating of each mutual fund by referring to sharpe method and Jansen method in 2017-2019.

\begin{tabular}{|c|c|c|c|}
\hline Year & Sharpe & Jensen & Level \\
\hline \multirow{5}{*}{2017} & $\begin{array}{l}\text { Batavia Dana Saham } \\
\text { Optimal }\end{array}$ & Sucorinvest Maxi Fund & 1 \\
\hline & BNP Paribas Solaris & $\begin{array}{l}\text { Manulife Saham SMC } \\
\text { Plus }\end{array}$ & 2 \\
\hline & Danamas & $\begin{array}{l}\text { Eastspring } \\
\text { Investments Value } \\
\text { Discovery Kelas A }\end{array}$ & 3 \\
\hline & $\begin{array}{ll}\text { Schroder } & \text { Dana } \\
\text { Prestasi Plus } & \end{array}$ & $\begin{array}{l}\text { Eastspring } \\
\text { Investments Alpha } \\
\text { Navigator }\end{array}$ & 4 \\
\hline & $\begin{array}{l}\text { Sucorinvest Equity } \\
\text { Fund }\end{array}$ & $\begin{array}{ll}\text { Simas } & \text { Saham } \\
\text { Unggulan } & \end{array}$ & 5 \\
\hline \multirow{5}{*}{2018} & Sucorinvest Maxi Fund & Trim Kapital & 1 \\
\hline & $\begin{array}{l}\text { Sucorinvest Equity } \\
\text { Fund }\end{array}$ & Batavia Dana Saham & 2 \\
\hline & BNP Paribas Solaris & $\begin{array}{l}\text { Eastspring } \\
\text { Investments } \quad \text { Alpha } \\
\text { Navigator }\end{array}$ & 3 \\
\hline & $\begin{array}{ll}\text { Schroder } & \text { Dana } \\
\text { Istimewa } & \end{array}$ & $\begin{array}{l}\text { Tram Infrastructure } \\
\text { Plus }\end{array}$ & 4 \\
\hline & $\begin{array}{ll}\text { Schroder } & \text { Dana } \\
\text { Prestasi } & \\
\end{array}$ & $\begin{array}{l}\text { Manulife Saham SMC } \\
\text { Plus }\end{array}$ & 5 \\
\hline \multirow{3}{*}{2019} & Sucorinvest Maxi Fund & $\begin{array}{ll}\text { Bahana } & \text { Trailblazer } \\
\text { Fund } & \\
\end{array}$ & 1 \\
\hline & $\begin{array}{ll}\text { Schroder } & \text { Dana } \\
\text { Prestasi Plus } & \\
\end{array}$ & Trim Kapital Plus & 2 \\
\hline & $\begin{array}{l}\text { Tram Infrastructure } \\
\text { Plus }\end{array}$ & BNP Paribas Solaris & 3 \\
\hline
\end{tabular}




\begin{tabular}{|l|l|l|l|}
\hline & $\begin{array}{l}\text { Simas Saham } \\
\text { Unggulan }\end{array}$ & BNP Paribas Ekuitas & 4 \\
\cline { 2 - 4 } & $\begin{array}{l}\text { Batavia Dana Saham } \\
\text { Optimal }\end{array}$ & Bahana Dana Prima & 5 \\
\hline
\end{tabular}

From the results of hypothesis three, the data above shows that the role of the investment manager is very large influence. For example, the role of investment managers is very influential, such as mutual fund products from BNP Paribas investment managers, namely BPN Paribas Solaris for three consecutive years $(2017,2018,2019)$ both sharpe method and jensen method suggests that investment managers from BNP Paribas always fall into the category of the top five best in performance.

\section{Conclusion}

This study aims to find out the best performance of stock mutual funds using Sharpe method, and Jensen based on 30 stock mutual funds with the largest managed funds at the end of December 2017, 2018 and 2019. The data obtained is then processed and analyzed descriptively quantitatively. The results of the analysis show:

For Sharpe method in 2017, the best performing stock mutual fund is Batavia Stock Fund Optimal Stock Fund. In 2018 and 2019, the best performance was the Sucorivest Maxi Fund.

For jensen method in 2017, the best performing stock mutual fund is Sucorivest Maxi Fund. In 2018, it showed the best performance, namely Trim Kapital Equity Fund. The Bahana Trailblazer Fund occupies the highest performance value in 2019.

The investment Manager who has the best performance for 3 consecutive years by looking at these two methods is BNP Paribas. BNP Paribas and other investment managers must maintain prudence in determining the types of stocks that want to be included in the mutual fund portfolio to be still able to generate a positive value of mutual fund performance. This will affect the investor's assessment of the performance of stock mutual funds using Sharpe method and Jensen method, not just judging from the ratios in stock mutual funds.

\section{References}

[1] Badan Pusat Statistik. (2020). Pendapatan Nasional Indonesia 2015-2019. Https://Www.Bps.Go.Id/. https://www.bps.go.id/publication/2020/06/12/7fe8d749c43bad46b1601662/pendapatan-nasional-indonesia-2015-2019.html

[2] Barus, G. A., \& Mahfud, M. K. (2013). Analisis Pengukuran Kinerja Reksa Dana Dengan Metode Sharpe Dan Metode Treynor (Studi Pada Reksa Dana Saham Periode Tahun 2011-2012). Diponegoro Journal of Management, 2(2), 1-11. http://ejournal-s1.undip.ac.id/index.php/dbr

[3] Beck, T., Levine, R., \& Loayza, N. (2000). Finance and the sources of growth. Journal of Financial Economics, 58(1-2), 261-300. https://doi.org/10.1016/S0304-405X(00)00072-6

[4] Chandra, A., \& Kumar, R. (2011). Determinants of Individual Investor Behaviour: An Orthogonal Linear Transformation Approach. MPRA Paper. ttps://ideas.repec.org/p/pra/mprapa/29722.html

[5] Creswell, J. W., \& Creswell, J. D. (2020). Research design: qualitative, quantitative, and mixed methods approaches.

[6] Gitman, L. J., Joehnk, M. D., Smart, S. B., \& Pearson. (2017). Fundamentals of investing. Pearson Education Limited.

[7] KSEI. (2020). Data Pertumbuhan Investor Baru. Www.Ksei.Co.Id. https://www.ksei.co.id/

[8] Northcott, A. (2014). Mutual Funds Book. Atlantic Publishing Group Inc. http://public.ebookcentral.proquest.com/choice/publicfullrecord.aspx?p=1852217

[9] Otoritas Jasa Keuangan (OJK). (2021). NAB Reksadana. Www.Ojk.Go.Id. https://reksadana.ojk.go.id/Public/StatistikNABReksadanaPublic.aspx

[10] Pramudena, S. M. (2020). Analysis on net profit earned by a company to dividend shared to investors (Case study of PT. Gudang Garam from 2014-2019). The Management Journal of Binaniaga, 5(01), 25. https://doi.org/10.33062/mjb.v5i01.373

[11] Pujiarti, T., \& Dewi, F. R. (2016). Analisis Kinerja Reksa Dana Saham Dengan Menggunakan Metode Sharpe Dan Jensen Untuk Periode 2005 - 2009. Jurnal Manajemen Dan Organisasi, 2(2), 97. https://doi.org/10.29244/jmo.v2i2.14199

[12] Sugiyono. (2018). Metode penelitian kuantitatif, kualitatif dan R\&D. Bandung: Alfabeta. http://opac.library.um.ac.id/oaipmh/../index.php?s_data=bp_buku\&s_field=0\&mod=b\&cat=3\&id=43665

[13] Sunariyah. (2010). Pengantar Pengetahuan Pasar Modal Edisi keenam. UPP STIM YKPN.

[14] Suryabrata., S. (2008). Metodologi penelitian.

[15] Tandelilin, E. (2001). Analisis Investasi dan Manajemen Risiko. BPFE. http://ucs.sulsellib.net//index.php?p=show_detail\&id=37871

[16] Tandelilin, E. (2010). Portofolio dan investasi: Teori dan aplikasi. Yogyakarta: Kanisius. http://opac.library.um.ac.id/oaipmh/../index.php?s_data=bp_buku\&s_field=0\&mod=b\&cat=3\&id=37132

[17] Untu, M. (2017). Perbandingan Kinerja Portofolio Optimal Berdasarkan Model Analisis Single Index Model (Sim), Capital Asset Pricing Model (Capm) Dan Arbitrage Pricing Theory (Apt) [E-Journal Universitas Atma Jaya Yogyakarta]. https://e-journal.uajy.ac.id/12089/

[18] Zu, Y. (2016). The role of mutual funds in the real economy. http://hdl.handle.net/11343/58372 